Jinak výsledky práce uvedeného týmu až překvapivě odpovídají $v$ mnohém tomu, co je známo i z výzkumu učitele v České republice: např. o nespokojenosti s extenzí aktivit a hlavně o vlastním pocitu učitele, že jeho pracovní vytiženost dává jen omezenou šanci využit čas pro vlastní výuku a př́pravu na ni. A také ovšem o tom, že pocit zaměstnanosti (ve smyslu zatíženosti) a zaměstnanost sama jsou dvě opravdu odlišné věci stejně jako míra deklarované nespokojenosti s pracovní situací a míra ochoty tuto práci prúpadně opustit.

Tím spíše jsme uvítali, že právě jedna ze spoluautorek studií doc. Sawako Yufu byla ochotna přispět $\mathrm{k}$ zajištění našeho malého komparativního šetření. Jak už dnes víme, tato drobná „pilotní ${ }^{\text {cc }}$ komparace při vši své limitovanosti přidala $\mathrm{k}$ prezentovanému obrazu učitele - na japonské i české straně - řadu dalšich charakteristik a hlavně inspirací.

Nejpodstatnější ze všeho je asi jedno pozoruhodné zjištěni:
Vezměte profesní vrstvu českých pedagogů se všemi peripetiemi různých sociálních zvratů a srovnejte ji s toutéž vrstvou jak v Británii (kde navzdory školské reformě jde neustále o sociálně klidný, evoluční vývoj), tak v Japonsku (kde od razantní změny po druhé světové válce uběhlo půl století). Navzdory všem těmto dějinným i mnoha dalším výrazným kulturním rozdílùm nakonec najdete docela základní a zcela zřetelnou shodu.

Ta shoda je překvapivě $v$ tom, co tyto lidi trápí, v čem se cítí být kvalifikováni a přitom sociálně diskvalifikováni a co současně také považují jen a jen za svou, v dané zemi a pro danou vrstvu specifickou situaci.

Možná někde tady, u tohoto fenoménu a fenoménủ analogických, se nalézá dobré východisko pro diferenciační a hloubkové systematické studium té které profesní nebo i vlastnické sociální skupiny či vrstvy.

\section{Richard Růžicka Yukino Sato}

\title{
Centrum pro kriminologický výzkum Univerzity Oxford
}

Díky laskavosti Oxford University Hospitality Scheme se autorovi těchto řádek poštěstilo v roce 1996 strávit měsíc ve stimulujícím prostředí, a to na pracovišti, které patř́ - po bo$\mathrm{ku}$ např. Institutu $\mathrm{v}$ Cambridge - $\mathrm{k}$ předním v Británii. Nepřevažuje zde ale orientace sociologická: již ze seznamu výzkumných témat uvedených $\mathrm{v}$ této stručné informaci vyplyne silná vazba na empirický výzkum souvislostí kriminologických a právních.

Hostitelské Centre for Criminological Research tvoři samostatnou jednotku $\mathrm{v}$ rámci univerzity, jejiž členové se podílejí na výuce (kurzu Zločinnost, právo a trestní systém) $\mathrm{v}$ rámci různých fakult či college. Pracuje v něm zhruba deset výzkumných pracovníků a dvě administrativní síly, dalších deset badatelů spolupracuje externě. V průběhu času se objevuji na kratší stáže ještě další, obvykle mladší pracovníci. Výzkumná činnost je založena na grantech získávaných $\mathrm{z}$ různých zdrojů: jisté komplikace zde působí okolnost, že státem subvencované projekty neumožňují dlouhodobějšś tematickou orientaci a perspektivu. Přesto jde o pracoviště, které vykazuje schopnost rozvoje - od roku 1996 zde byla ustavena Jednotka probačních studií (vedená $\mathrm{R}$. Burnettem) se samostatným výzkumným programem.

Ředitelem Centra je Dr. Roger Hood, člen All Souls College a edični rady European Journal of Crime, Criminal Law and Criminal Justice. Je předním světovým expertem, podílel se napr. na studii Amnesty International v USA 1993 o trestu smrti, byl konzultantem OSN pro mezinárodní výzkum trestu smrti (1989 - 1995). Pod jeho vedením vychází $v$ Oxford University Press řada Clarendon Studies in Criminology. Velký ohlas měly jeho posledni dvě publikace: Race and Sentencing (Clarendon Press, Oxford, 1992) určená Komisi pro rasovou rovnoprávnost, a druhé vydání knihy The Death Penalty. A World-wide Perspective (Clarendon Press, Oxford, 1996, 307 s.). Studie o trestu smrti prináší nejaktuálnější údaje o stavu problematiky a má celosvětový význam. 
$\mathrm{V}$ posledních letech bylo dokončeno několik výzkumných projektů:

- Typologie násilné trestné činnosti

- Grendon: Studie terapeutické věznice

- Ozbrojené loupeže (S. Morrison, I. O’Donnell)

- Rasově motivované incidenty ve vězení ( $R$. Burnett, G. Farrell)

- Analýza podmíněného propuštění ( $\mathrm{R}$ : Hood, S. Shute - dvě etapy)

- Trestní právo

V současnosti probíhaji výzkumy

- mentálně handicapovaných obětí (svědků)

- viktimizace („šikanováníc) ve věznicích

- probační studie hodnocení pachatele

- srovnávací výzkum sociálního řádu, trestního práva a komunity v Anglii a v Německu

- kvalitativní výzkum intergeneračních rozdílů v chápání zločinu a spravedlnosti založený na životních příbězich ( $v$ londýnském East-endu)

- komunitního dozoru nad pachatelem

- rasově motivovaného zločinu v Evropě
- kolumbijských žen (drogových kurýrů) uvězněných v Evropě.

Za poslední dva roky se objevilo šest doktorandských prací. Centrum organizovalo řadu dalších seminářů. Byla také obnovena tradice specializované vědecké společnosti a jejích diskusních setkání - The Oxford Crime Forum.

Probíhající výzkumy se vyznačují hloubkou záběru i flexibilitou použivaných metod, zřetelná je vazba na praktické otázh! trestní a bezpečnostní politiky, přitom zachovávajicí kritický odstup. Přinejmenším někteří $z$ výzkumnikủ se zcela samozřejmě pohybují v terénu vzdáleném na hony akademickému prostředí. Pro českého sociologa však zůstává největším zážitkem návštěva historických prostor věhlasné All Souls College: uzavřít se před vnějším světem do takových knihoven a pracoven je opravdu radost. Také Oxford již praská ve švech pod náporem turistů...

Jiři Buriánek 